Geological Society, London, Special Publications

\title{
Palaeomagnetic constraints on the evolution of the Caledonian-Appalachian orogen
}

J. C. Briden, D. V. Kent, P. L. Lapointe, J. L. Roy, R. A. Livermore, A. G. Smith, M. K. Seguin, R. Van der Voo and D. R. Watts

Geological Society, London, Special Publications 1988, v.38; p35-48.

doi: 10.1144/GSL.SP.1988.038.01.03

\section{Email alerting service}

Permission request

Subscribe click here to receive free e-mail alerts when new articles cite this article

click here to seek permission to re-use all or part of this article

click here to subscribe to Geological Society, London, Special Publications or the Lyell Collection

\section{Notes}




\title{
Palaeomagnetic constraints on the evolution of the Caledonian- Appalachian orogen
}

\author{
J. C. Briden, D. V. Kent, P. L. Lapointe, R. A. Livermore, J. L. Roy, \\ M. K. Seguin, A. G. Smith, R. Van der Voo \& D. R. Watts
}

\begin{abstract}
SUMMARY : Late Proterozoic and Palaeozoic (pre-Permian) palaeomagnetic data from all regions involved in, or adjacent to, the Caledonian-Appalachian orogenic belt are reviewed. Between about 1100 and about $800 \mathrm{Ma}$ the Laurentian and Baltic shields were close together, prior to the opening phase of the Caledonian-Appalachian Wilson cycle. The problems of tectonic interpretation of Palaeozoic palaeomagnetic data from within and around the belt derive mostly from differences of typically $10^{\circ}-20^{\circ}$ between the pole positions. These can variously be interpreted in terms of (i) relative displacements between different continents or terranes, (ii) differences in ages of remanence and (iii) aberrations due to inadequacy of data or geomagnetic complexity, and it is not always easy to discriminate between these alternatives. If the Pangaea A2 reassembly of continents around the northern and central Atlantic is taken as the end-product of Caledonian-Appalachian orogenesis, the following conclusions can be drawn.

1 Lower Palaeozoic palaeolatitude differences between the $\mathrm{N}$ American and BritishScandinavian margins of the Caledonides are small; hence any convergence must have been mainly E-W.

2 There are additional differences which could be due to major pre-Carboniferous strikeslip (more than $1000 \mathrm{~km}$ ), although later strike-slip on this scale is no longer considered likely.

3 The Lower Palaeozoic apparent polar wander paths for Northern Scotland and $\mathrm{N}$ America disagree on face value, but must be reconciled if their conventionally assumed geographic relation is correct.

4 Lower Old Red Sandstone data from Britain and Norway disagree, but this is more likely to be due to magnetic overprinting in the Norwegian rocks than to remnant oceans between the regions of Old Red Sandstone facies.

5 Armorica seems to have been far to the S, adjacent to Gondwana, in Ordovician time. The latest view is that it collided with Euramerica in early Devonian time to form the Old Red Continent.

6 The timing of Gondwana's collision with the Old Red Continent is controversial; it is within either the late Devonian or the Carboniferous. If it occurred early in that time range, much of Hercynian-Alleghanian orogeny post-dated it.
\end{abstract}

Palaeomagnetic data from the continental crust were crucial in the recognition of Wegenerian continental drift which consists principally of the fragmentation and dispersal of Pangaea from Mesozoic times onward. However, limitations of precision and the indeterminacy of longitude which arises from the axial symmetry of the timeaveraged palaeomagnetic field prevented the deduction of adequate and unique maps of the sequence of events. Simpler and more precise palaeomagnetic and tectonic data from the oceanic crust were required to achieve precise reassembly of relative positions and, once these were available, the principal role of continental data was to place those reassemblies into a latitude-longitude framework.

The application of continental palaeomagnetism to Palaeozoic continent distribution is even more hazardous than is the case for Mesozoic and younger periods for a number of reasons.
1 There is no additional constraint from contemporary oceanic crust, since none is preserved other than as ophiolite fragments.

2 The definition of Palaeozoic lithospheric fragments - plates and terranes - is not always clear.

3 There are insufficient data to chart the progress of all these fragments relative to the pole.

4 In general, older rocks are palaeomagnetically more complex. Whether by involvement in orogeny or by long-term exposure to geomorphological processes, older rocks are more likely to have been at least partially remagnetized. The dissection of the various magnetizations coexisting in such rocks is never straightforward and is sometimes impossible.

5 Problems of dating magnetizations are severe. Not only are there problems of dating the rocks themselves and of relating biostratigraphic and 
radiometric ages into an internally consistent scale, but there are also problems in relating magnetization components to datable events in the formation and subsequent history of those rocks, e.g. in red beds.

It follows that useful palaeomagnetic constraints on the evolution of an orogenic belt are best derived from sequences of precise dated palaeomagnetic field estimates from individual lithospheric fragments. Precision is vital because relative movements of the order of hundreds of kilometres or less are of key interest to students of the geology of orogeny. Sequences of data are necessary because the required order of precision is rarely attained in single rock formations. Dating is vital because relative ages of events are a key element in the pattern of tectonic evolution.

In the case of the Appalachian-Caledonian orogen the definition of terranes within the belt is still a matter of debate, the identity and character of much of the SE margin is uncertain and the geological record on the cratons available for palaeomagnetic sampling is far from adequate; it also emerges that much of the apparent polar wander (APW) that is found corresponds to a change in palaeo-orientation rather than palaeolatitude.

Hence the approach we take here is to assume that the major fragments of continental lithosphere in the lower Palaeozoic were Baltica, Gondwanaland, Laurentia and Siberia, which would progressively be sutured along the Caledonian, Appalachian, Hercynian and Uralian orogenic belts to form a Pangaea at least by late Palaeozoic times. We shall consider the motion of each of these blocks in so far as they are relevant to the Appalachian-Caledonian orogen, and we shall also consider marginal regions of those 'continents' within the orogen, and those possible microcontinental fragments caught up within the belt, for which there are any palaeomagnetic data.

The palaeomagnetic expression of plate convergence related to the Caledonides was first illustrated schematically as differences between 'European' and 'N American' Palaeozoic polar wander paths relative to the geometrical fits of Bullard et al. (1965) and of Smith \& Hallam (1970) now called Pangaea A, by Briden et al. (1973) and McElhinny (1973). The obvious place to try to measure the amount of separation was the British Isles, which is the only place where the whole width of the belt is exposed on land, but early attempts (Briden et al. 1973, Piper 1979) were rather inconclusive owing to scatter in the data. A direct comparison of poles from two contemporaneous volcanic suites in Ireland
(Deutsch 1980) and a more generalized estimate based on sequences of data, some of it more refined than hitherto, by Briden et al. (1984) are more satisfactory. Van der Voo and co-workers (Van der Voo 1979, Hagstrum et al. 1980, Perroud et al. 1984) have extended the comparisons to embrace 'Armorica', which is hypothetically an Armorica plate consisting not only of the Armorican massif but of most of Hercynian Europe, probably the Avalonian terranes of northeastern $\mathrm{N}$ America and possibly southern England and Wales.

Morris (1976) pointed out that the long-known discrepancy between European and N American Ordovician-Devonian data on the base map of Bullard et al. (1965) was consistent with major transcurrent movement roughly along the present Atlantic margin.

Features such as these have been incorporated into palaeocontinental world maps on a variety of scales and generalizations (Smith et al. 1973, 1981, Zonenshayn \& Gorodnitskiy 1977a, b, Kanasewich et al. 1978, Morel \& Irving 1978, Scotese et al. 1979, Bambach et al. 1980, Turner \& Tarling 1982, Scotese 1984, Livermore et al. 1985).

We have endeavoured to confine our considerations to data which can be considered reliable in terms of their sampling, magnetic cleaning and dating. We have not applied stringent numerical criteria for rejection. This would lead to the elimination of a large proportion of the data ( $c f$. the small number of grade A poles listed by Briden \& Duff(1981)). Moreover, rigid criteria are not favoured because it is unclear what number of samples is required to eliminate bias; samples may not actually be independent in the statistical sense, and small confidence limits may indicate high quality or simply failure to sample secular variation adequately. Further, the methods and standards of analysis vary between laboratories, e.g. in the averaging of palaeomagnetic directions or VGPs and in the calculation of error limits. Rather, those poles considered most reliable by palaeomagnetists familiar with the results from each continent or continental fragment have been sought. The poles used all conform to the minimum rejection criteria set out by McElhinny (1973).

\section{Laurentia}

Laurentia comprises N America, Greenland, W Spitzbergen, Rockall and NW Scotland. Its reassembly in the configuration of Bullard et al. (1965) is generally consistent with geological constraints, most importantly the continuity of 
Archaean ('Lewisian') and Proterozoic ('Grenville') basement and lower Palaeozoic cover (Durness and Beekmantown sequences) across the Atlantic. Of course, in Lower Palaeozoic time Laurentia would have presented a somewhat different outline from now, since its margins have subsequently been much modified.

The polar wander path for the interval between 1150 and $820 \mathrm{Ma}$ is documented by a comparatively high density of pole positions comprising the Keweenawan track and the Grenville track. The Keweenawan track is determined by poles from Keweenawan volcanics, intrusives and sediments, and is supported by data from the Proterozoic Grand Canyon sequence. The later Grenville track is derived almost entirely from intrusions which cooled slowly in the Grenville Province after the peak metamorphic event, often resulting in complex multi-vector palaeomagnetic records. The Grenville poles are now regarded as representative of Laurentia because similar poles have been identified outside the Grenville Province. The precise connection of the Grenville track with the Keweenawan track is equivocal. The continuous joined paths shown in Fig. 1 are from recent reviews (Buchan et al. 1983, Roy 1983), with the two tracks connected near the equator and the Grenville poles forming a counterclockwise loop ( $\mathrm{S}$ poles) in the eastern hemisphere. The age calibration of the Keeweenawan track is uncertain by $\pm 50 \mathrm{Ma}$ (Roy 1983), and the Grenville track is perhaps better dated by ${ }^{40} \mathrm{Ar} /{ }^{39} \mathrm{Ar}$ dating of mineral separates (Buchan et al. 1983). The poles in the highest latitudes on the Keweenawan track may be the result of asymmetry between mean directions of palaeo-

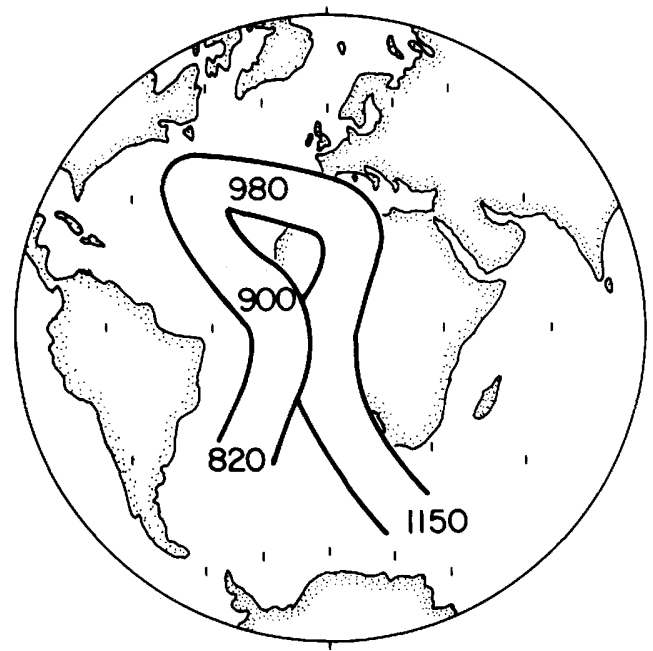

FIG. 1. Combined Keweenawan and Grenville APW paths (ages in Ma) (Redrawn after Buchan et al. 1983.) magnetic fields of opposite polarity during Keweenawan time (Nevanlinna \& Pesonen 1983).

Palaeomagnetic poles from the Stoer Group and the Torridon Group of the NW Highlands of Scotland fall on the Keweenawan track when rotated into the $\mathrm{N}$ American frame of reference using a reconstruction (Smith et al. 1983) in the style of Bullard et al. (1965). This implies that the age of magnetization of these sediments is between 1100 and $1050 \mathrm{Ma}$, contrasting with the $\mathrm{Rb}$-Sr closure ages of $968 \mathrm{Ma}$ for the Stoer Group and $777 \mathrm{Ma}$ for the Torridon Group. This discrepancy is open to a number of interpretations.

The polar wander track for Laurentia between $820 \mathrm{Ma}$ ago and early Palaeozoic time is highly problematical because of the low density of pole determinations for this interval. Published interpretations have been criticized because they are based mainly on undated secondary magnetizations (McCabe \& Van der Voo 1983, Roy 1983). A substantially larger data base is required for this interval before any consensus on the nature of the Laurentia polar wander path for this interval is reached.

Notwithstanding increasingly intensive study over the past 30 years, the Palaeozoic APW path for N America remains controversial. Almost all pole positions from upper Ordovician and younger rocks lie within $20^{\circ}$ of the PermoCarboniferous poles suggesting either that $\mathbf{N}$ America moved less relative to the poles in that time than any other fragment that has been palaeomagnetically studied $o r$ that the remanence of these rocks is dominated by Permo-Carboniferous overprints so that the mid-Palaeozoic APW of America is not yet fully discovered. Such a conclusion is implicit in the interpretation of Seguin \& Gahé (1985). The remagnetization hypothesis was first proposed by Creer (1968) and has been convincingly documented in several specific cases (e.g. Roy et al. 1967, French \& Van der Voo 1977, Irving \& Strong 1984a, Kent \& Opdyke 1985). More generally, it is suggested by the observations that Cambrian poles are spread along a line from the equatorial W Pacific to the vicinity of Permo-Carboniferous poles (Roy et al. 1983).

Those poles from Ordovician, Silurian and Devonian rocks which do not group close to Permo-Carboniferous poles are instead scattered roughly along the $30^{\circ} \mathrm{N}$ latitude line between about $160^{\circ} \mathrm{E}$ and $80^{\circ} \mathrm{E}$ with no clear chronological order to them (Roy et al. 1983), suggesting that overprinting was not restricted to Permo-Carboniferous time. Seguin \& Michaud (1985) reached this conclusion in the case of sediments from the St Lawrence Lowlands. 
Although more elaborate paths which imply extremely rapid and complex APW have been proposed (Dankers 1982), the path drawn by Van der Voo et al. (1980) (see also Van der Voo 1981) which is updated in Fig. 2 has been widely accepted as the best available estimate of the motion of the craton.

On this basis divergent data from lower Carboniferous and older rocks from the Appalachians have been interpreted as evidence for large-scale sinistral transcurrent motion (Kent \& Opdyke 1979, Van der Voo et al. 1979, Kent 1982) and/or rotation (Spariosu \& Kent 1983) of terranes within the Appalachians. However, this interpretation has been disputed (Roy 1982), and not all data from the belt conflict with that from the craton (Roy et al. 1983, Seguin et al. 1985). Moreover, Irving \& Strong (1984b) have recently argued that what was originally interpreted as a pole position divergent from that applicable to the craton may instead be typical of the craton, while in other cases the presumed primary NRMs of cratonic rocks are now realized to be late Palaeozoic overprints (Kent \& Opdyke 1985). Hence the notion of large-scale transcurrent motion in Carboniferous and later time is now discounted and hence, paradoxically, many of the best estimates of the N American APW path may have been derived from its deformed margin rather than its stable interior. If so, this may be because the rocks from the orogenic belt were

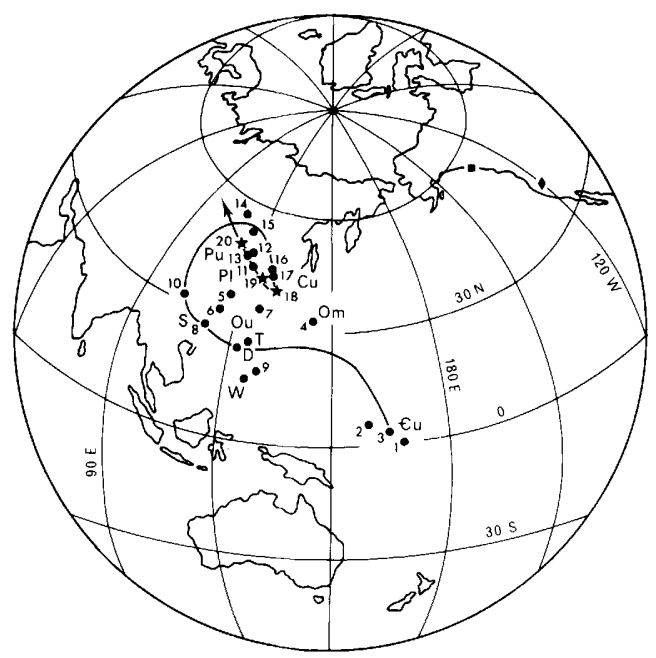

FIG. 2. Palaeozoic APW path for N America according to Van der Voo et al. (1980) where most of the data are listed. Additional data are as follows: pole 9 revised after French \& Van der Voo (1979); W, Wabash limestone (McCabe et al. 1985); T, Terenceville Formation (Kent 1982); D, Deer Lake Group (Irving \& Strong 1984a). indurated and thus protected from the promotion of diagenesis by circulating groundwater, while the cratonic rocks were vulnerable to the effects of such processes (Irving \& Strong 1984b, Seguin \& Michaud 1985).

The lower Palaeozoic and Devonian APW paths for Scotland $\mathrm{N}$ of the Iapetus suture (Fig. 3A, B) are updated from Briden et al. (1984) and are extended into the lower Carboniferous. The data are entirely from igneous rocks, which are mostly intrusive, and high-grade metamorphic rocks. Although only a minority of the poles are dated directly, correlation is generally fairly well constrained by stratigraphic control and petrological affinity. As in $\mathrm{N}$ America red sediments appear to have been totally remagnetized in Permo-Carboniferous times (Tarling et al. 1976), and these data are omitted. Briden et al. (1984) sought to demonstrate that within these parts of Scotland there was no significant difference between the data from $\mathrm{N}$ and $\mathrm{S}$ of the Great Glen (compare Figs 3A and 3B), contrary to the conclusions of Van der Voo \& Scotese (1981).

In Fig. 4 the $\mathrm{N}$ American data (Fig. 2) are rotated to Europe after Bullard et al. (1965). Comparison with Fig. 3 shows that on this reassembly the bulk of $\mathrm{N}$ American poles lie in systematically higher latitudes than is the case for the Scottish poles. This is consistent with a configuration like that proposed by Kent \& Keppie (1987, Fig. 1) and subsequent sinistral shear. However, the most reliable of the critical N American data do not show this discrepancy; in particular, the Silurian data from the Rose Hill and Wabash Formations ( 9 and $\mathrm{W}$ in Fig. 4) are not significantly different from the poles from some of the Newer Granites in Scotland (HG, R and SG in Fig. 3A). Also, the paths from both regions backtrack together in the Lower Carboniferous. Thus it is possible that there may be a common APW path for Laurentia from Ordovician times to the end of the Palaeozoic; if this is so, it has the advantages of (a) not violating the widely accepted geometrical and geological reassembly, (b) not requiring transcurrent displacements younger than Caledonian age and (c) not requiring displacements of areas usually regarded as essentially part of the craton (Spariosu \& Kent 1983).

\section{Baltica}

We refer to Baltica as the region bounded by the Caledonian, Uralian and Hercynian belts, and therefore consisting principally of Scandinavia and the Russian-central European platform, with Britain (S of the Iapetus suture) possibly at its 

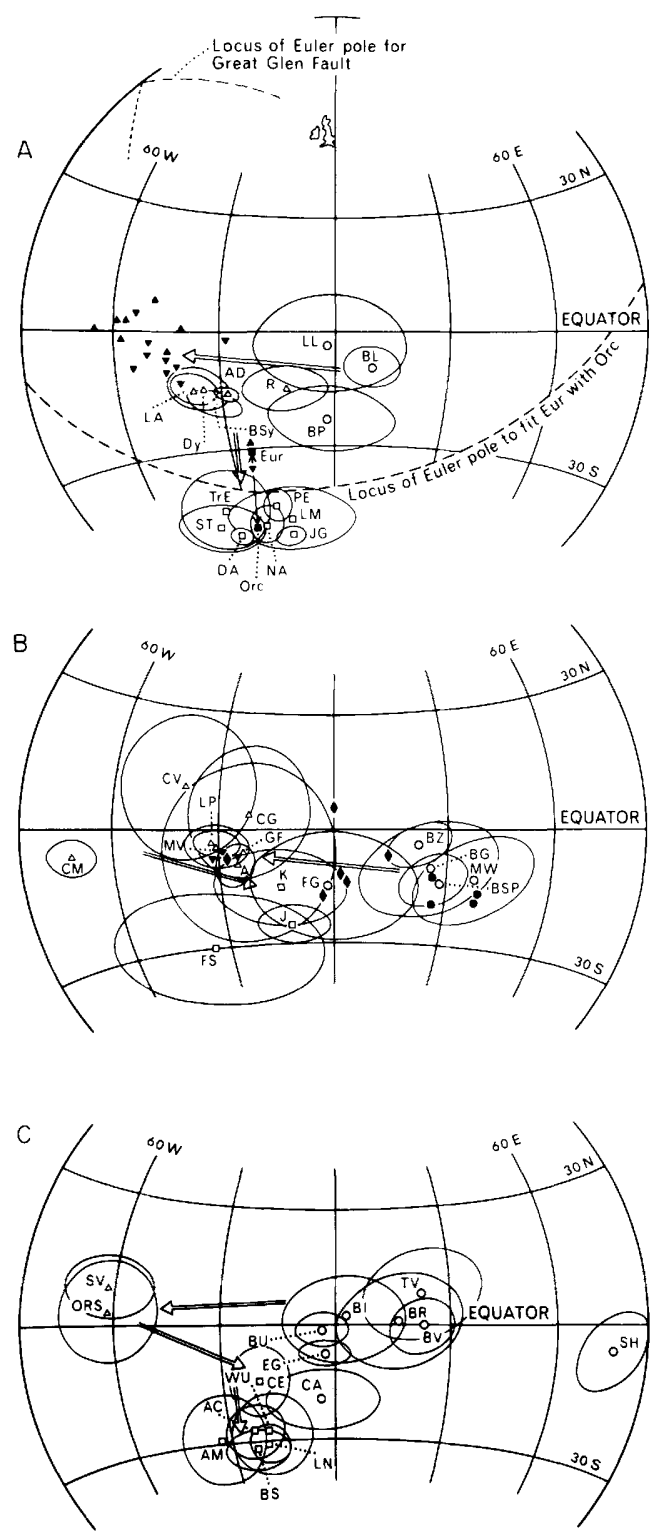

FIG. 3. Palaeozoic APW paths for three regions of the British Isles (A) N of the Great Glen fault, (B) between the Great Glen fault and the Solway line, and (C) $\mathrm{S}$ of the Solway line, with mean poles from other relevant areas: $O$, poles from Ordovician formations; $\Delta$, Silurian-early Devonian; $\square$, mid-Devonian and younger Palaeozoic. The $95 \%$ confidence limits are shown in all cases. Full symbols denote data from single sites. The data are from Briden et al. (1984), where the notation and sources are given, with additions as follows: FG, Foyers granite revised after Torsvik (1984); HG, Helmsdale granite (Torsvik et al. 1983); SG, Strontian grantie (Torsvik 1984); K, Kinghorn lavas (Everitt \& Belshé 1960); CE, mean Carboniferous of England and Wales (Irving 1964). western extremity, and central and eastern Spitzbergen and Novaya Zemlya on its northern flank. However, it is not clear for what period of time Baltica, as thus defined, was a tectonic entity, and the palaeomagnetic data base is so uneven, mainly because of the partiality of the stratigraphic record, that relative motions between parts of the region cannot be well defined at present.

A high density of pole determinations for the interval from 1040 to $840 \mathrm{Ma}$ is available for Baltica, mainly from the Sveconorwegian fold belt which probably correlates with the Grenville province. This polar wander path is shown in Fig. 5. The palaeomagnetic poles span the same interval as the Grenville track, but the interpretation depicted in Fig. 5 shows the Baltic poles describing a clockwise path in the eastern hemisphere, opposite to the sense of movement depicted for the Grenville track as interpreted by various $\mathbf{N}$ American workers. Imprecision in the dating and location of the poles may be a factor in this ambiguity, and the Baltica polar wander path requires more precise calibration by ${ }^{40} \mathrm{Ar} /$ ${ }^{39} \mathrm{Ar}$ age determinations as has been done for the Grenville track. Peripheral parts of Baltica may have been accreted during Proterozoic time, but there are no palaeomagnetic data to delimit this.

In the Palaeozoic the palaeomagnetic data distribution within Baltica is reversed and is concentrated in the peripheral regions such as Britain. Hence the data are again inadequate to determine when the present relative configuration was attained. In particular, the position of Scandinavia relative to southern Britain is not

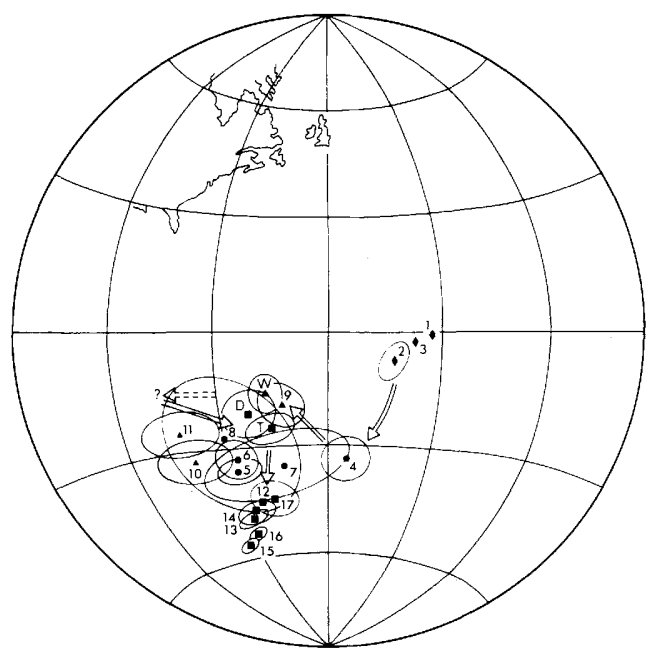

Fig. 4. N American data of Fig. 2 rotated to Europe after Bullard et al. (1965), plotted as South APW path and annotated for comparison with Fig. 3. 


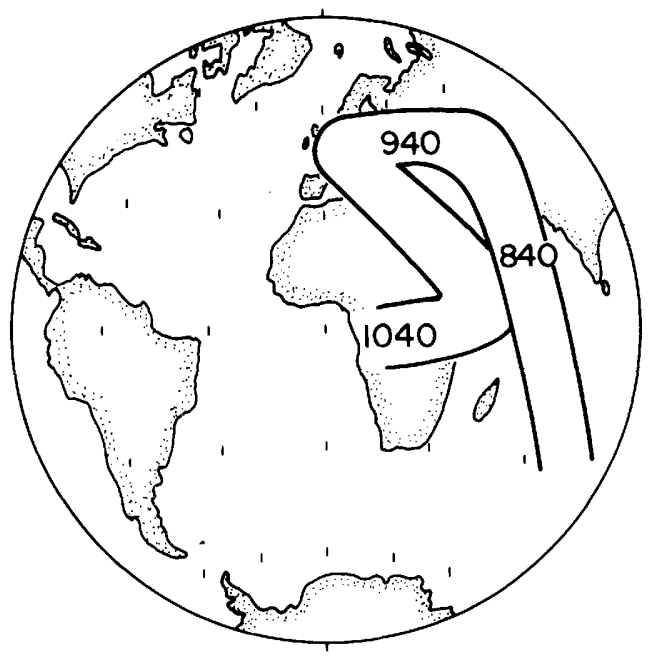

FIG. 5. APW path for Baltica for the interval 1040840 Ma. (After Stearn \& Piper 1984.)

determined. Hence, most unfortunately, data are inadequate to throw light on the possible evolution of the 'third arm' of the Caledonides through central Europe except to indicate that the Russian Cambro-Ordovician and British Ordovician palaeolatitudes were similar but that their orientations were very different from the present; this may imply substantial closure and relative rotation in later Lower Palaeozoic time.

All Cambrian sediments from Britain that have been studied (Briden et al. 1971, 1973, Claesson \& Turner 1980) seem to have been remagnetized. Southern Britain, however, does provide a number of reasonably constrained Ordovician and Silurian data. Although the Lower Devonian is only represented by the pole from the Anglo-Welsh Old Red Sandstone (Chamalaun \& Creer 1964), McClelland Brown (1983) has confirmed this and demonstrated that the primary remanence has been distinguished from the strong Permo-Carboniferous overprint. Hence the APW path for southern Britain (Fig. 3C) heads westward as does the path for Scotland (Fig. 3A, B), although in the former case it may be exaggerated by about $20^{\circ}$ of fairly local clockwise rotation which deflects the regional Caledonoid trend in the Old Red Sandstone of $\mathrm{W}$ Wales. As with Laurentia, the path then backtracks in the Lower Carboniferous before heading to higher latitudes (about $30^{\circ}$ ) in later Carboniferous times.

Scandinavia provides fragmentary data including only four of Lower Palaeozoic age. The three possibly Cambrian poles, from the Alnö and Fen complexes and the Nexø sandstone, differ greatly and it is premature to suggest an APW path (Piper 1981). That from the Ordovician Sulitjelma gabbro is of uncertain regional significance because of its allochthonous tectonic situation. There are three poles from the Norwegian Old Red Sandstone, all located approximately $20^{\circ} \mathrm{S}$, $345^{\circ} \mathrm{E}$ and thus differing from the results from Britain and seeming to imply a 'Tornquist's Sea' up to $1000 \mathrm{~km}$ wide at this time (Kent \& Keppie 1987, Fig. 1). However, this interpretation involves major separations between components of the Old Red Sandstone continent when the Old Red facies was already widely developed. Since the British data are corroborated by evidence from contemporaneous extrusive and intrusive igneous rocks while the Russian and Norwegian data are all from sediments and fall on later Palaeozoic parts of the British APW path, an alternative explanation of this difference is that the original NRM in the sediments has been overprinted.

For the Russian platform (Khramov et al. 1981) there are Cambro-Ordovician data which are regarded as reliable, but Ordovician, Silurian and early Devonian data are believed to have been affected by partial or total overprinting in the late Palaeozoic. Thus although Khramov et al. (1981) elicited some control on the position of the Russian platform in the Ordovician and Silurian using data from the Urals, these are insufficient to provide a reliable APW path (Fig. 6A).

\section{Armorica}

Van der Voo (1979) and Hagstrum et al. (1980) suggested, largely on palaeomagnetic grounds but augmented by geological argument, that the Armorican massif, together with the Bohemian massif, England and Wales and the Avalonian terranes of NE America, was part of a somewhat larger lithospheric plate 'Armorica' throughout much of Palaeozoic time. They argued that Armorica was still in high southerly latitudes in the early Ordovician (see the end of the APW path in Fig. 6(B) and Fig. 8(A)) but moved northwards to collide with $\mathrm{N}$ America in the Taconic orogeny. Perroud et al. (1984) have revised the estimate of collision to coincide with the Acadian orogeny and also pointed out that Armorica could have been a 'mosaic of tectonic elements ... more or less at the same latitude' rather than a single plate.

The incorporation of Central Britain between the Hercynian front and the Iapetus suture into Armorica rests upon inconclusive late Proterozoic and Cambrian palaeomagnetic data and upon 

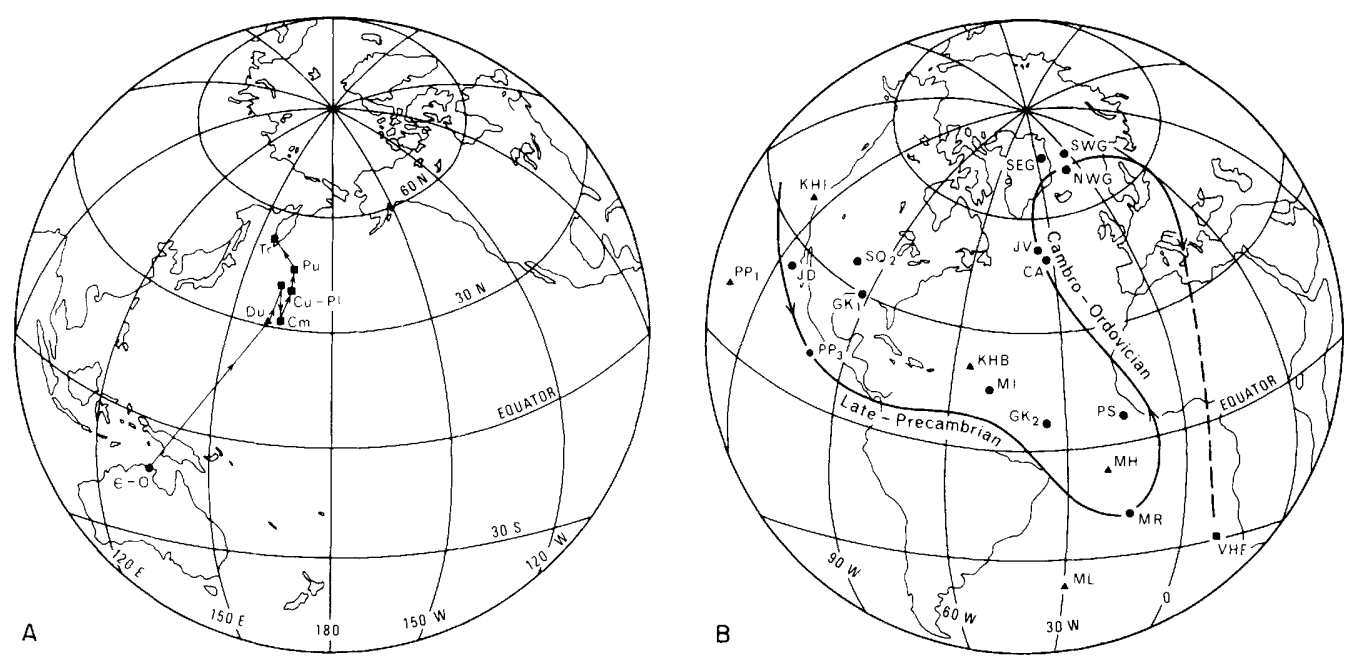

FIG. 6. Palaeozoic APW path for (A) the Russian platform (redrawn from Khramov et al. 1981) and (B) Armorica (Hagstrum et al. (1980) updated by Perigo et al. (1983) from where this map was redrawn). (Approximate stratigraphic ages and the middle Devonian to lower Carboniferous pole (VHF) from the Vosges, Harz and Franconian Forest (Bachtadse et al. 1983) have been added.)

uncharacteristically high inclinations (e.g. Thomas \& Briden 1976) among a large body of Ordovician data which indicate lower latitudes $\left(30^{\circ}-43^{\circ} \mathrm{S}\right)$ than those of the Armorican massif $\left(46^{\circ}-76^{\circ} \mathrm{S}\right)$. Hence we regard central Britain as marginal to Baltica and not Armorica, and have discussed it in the previous section. This is contrary to the geologically based inferences of Ziegler (1984) that the London platform and Irish Sea horst belong to the same block as the Armorican and Bohemian massifs, unless we have been misled by the palaeomagnetic results from the latter regions. It should also be pointed out that the affinity of Avalonia and other marginal terranes of $\mathbf{N}$ America to Armorica is equivocal. However, the role of Armorica, even if it embraces no more than the stretch of Hercynian Europe from the Armorican to the Bohemian massif, is important to the tectonic evolution of the region as will be shown in the next section.

\section{Relative positions of the crustal blocks}

The palaeomagnetic data summarized in the foregoing sections provide control on the palaeolatitude and orientation of each crustal fragment, with uncertainties which amount to several degrees of arc (i.e. at least several hundred kilometres) at the $95 \%$ confidence level. The relative longitude remains indeterminate so that formal estimates of the separation of fragments will always be minima and will be measured by differences in palaeolatitude only; it is for this reason that compilers of Palaeozoic world 'maps' (e.g. Smith et al. 1973) often refer to them as 'composites' rather than true maps. Control on actual palaeolongitudinal separation relies on rather generalized geological constraints, such as the timing of the eventual suturing of two margins, together with the assumption that plate velocities have not been an order of magnitude larger than the present maximum. In particular, the need to assemble Pangaea by the end of the Palaeozoic is a major constraint.

The arrangement of Pangaea that is usually considered is the least-squares continental fit (Bullard et al. 1965, Smith \& Hallam 1970), now often called Pangaea A, which fits a great deal of continental geological evidence as well as seafloor spreading data. However, as has been realized for many years (van Hilten 1964), Permian and early Triassic palaeomagnetic data from Laurasia and Gondwanaland do not conform to this reconstruction but are better fitted with the northern continents displaced westward (anticlockwise) relative to Gondwana (Van der Voo \& French 1974, Van der Voo et al. 1976, Van der Voo et al. 1984) in the arrangement called Pangaea A2 by Morel \& Irving (1981). This route has been followed by Livermore et al. (1985). 


\section{Precambrian}

Fragments of a late Proterozoic reconstruction can be glimpsed in the available palaeomagnetic data. If the correlation of the Stoer and Torridonian poles with the Keweenawan poles is correct, i.e. older than their $\mathrm{Rb}-\mathrm{Sr}$ closure ages, the fragment of Precambrian crust in the NW Highlands of Scotland must be placed near the position proposed by Bullard et al. (1965). However, this conclusion remains uncertain in the absence of direct confirmation of the age of remanence.

Grenville poles and contemporaneous poles from Baltica are consistent with a reconstruction in which Baltica lies against Laurentia and the Grenville Province is continuous with the Sveconorwegian belt (Stearn \& Piper 1984). Baltica is $15^{\circ}-20^{\circ} \mathrm{S}$ of the Bullard et al. (1965) fit in a position similar to some suggested Devonian reconstructions (e.g. Kent \& Keppie 1988).

\section{Cambrian and Ordovician}

As the discussion of the palaeomagnetic data shows, maps of Cambrian and Lower Ordovician time are necessarily very speculative, at least as far as the continents bounding the Caledonides are concerned. Smith et al. (1973, 1981), Scotese et al. (1979) and Morel \& Irving (1978) have all produced tentative versions, and while they differ greatly they have in common the placement of most major fragments in low latitude. Likewise, maps for later Ordovician time show Laurentia and Baltica in low latitudes, with Iapetus lying at $0-30^{\circ} \mathrm{S}$.

In Fig. 7(A) (Livermore et al. 1985), which relates to late Ordovician-early Silurian times, Baltica is positioned on the basis of data mostly from England and Wales. Interpolation of the APW path from the Russian platform would put Baltica in a different orientation but a similar latitude. Laurentia is positioned on the basis of $\mathrm{N}$ American data; the difference between Laurentia and Baltica data implies a latitudinal width of about $2000 \mathrm{~km}$ for the lapetus ocean, which is twice as wide as that estimated from the difference between data from England-Wales and Scotland alone (Briden et al. 1984). Thus, taken at face value, the palaeomagnetic data would place Scotland in Fig. 7(A) in the middle of the Iapetus ocean which would pose major geological problems. Figure 7(A) is a cartographic expression of the discrepancies between the Scottish and $\mathrm{N}$ American data discussed at the end of the section on Laurentia. Some regions of the Appalachians are positioned on the $\mathrm{S}$ side of Iapetus in this map, in conformity with some palaeomagnetic data (Lapointe 1979, Rao \& Van der Voo 1979). This emphasizes that early or middle Palaeozoic closure and transcurrent movement within the Appalachians remain a distinct likelihood notwithstanding doubts about the reality of late Palaeozoic transcurrent displacement. Armorica and the southern Appalachians are both shown at about $60^{\circ} \mathrm{S}$.

The Ordovician sketch map due to Perroud et al. (1984) (Fig. 8A) is essentially the same as Fig. 7(A) except in its treatment of central Britain as part of Armorica rather than Baltica. That association is not well supported by the palaeomagnetic evidence which indicates that Britain was in a significantly lower palaeolatitude. Duff (1980) associated both regions with the Baltic shield and drew a common APW path, but this depended heavily on similarity between data from the Fen complex (Norway) and results of a bare reconnaissance nature from igneous rocks in Leicestershire and slates from $\mathbf{N}$ Wales.

\section{Silurian and Devonian}

In the first of their alternative maps for the SiluroDevonian boundary (Fig. 7B) Livermore et al. (1985) show Iapetus still up to $1000 \mathrm{~km}$ wide or more. On this map Baltica is shown in a position indicated by poles from the Norwegian Old Red Sandstone and from Avalonia. Cratonic N America is positioned separately, using the poles from the Peel Sound Formation and the Bloomsburg Formation. These choices of data imply that Baltica was offset dextrally from its Bullard et al. (1965) position relative to Laurentia, i.e. prior to sinistral displacements along the CaledonianAppalachian belt ( $c f$. Van der Voo \& Scotese 1981).

If, instead, Laurasia were oriented as a single unit based on British and N American data from the Caledonian-Appalachian belt, the southern margin of the $\mathrm{N}$ American craton would be at nearly $60^{\circ} \mathrm{S}$. This raises difficulties in relation to the Gondwana data (Kent et al. 1984, Livermore et al. 1985) as well as indicating that a version of Pangaea was already assembled as early as endSilurian time.

For the early Devonian, Perroud et al. (1984) (Fig. 8B) show Laurentia and Baltica in positions not unlike those shown in Fig. 7(B), but with Armorica already adjacent.

\section{Carboniferous}

Figure 7(C) shows a map proposed by Livermore et al. (1985) for Eifelian-Tournasian time. It is based on various assumptions about the palaeomagnetic data, faunal provinciality and the 

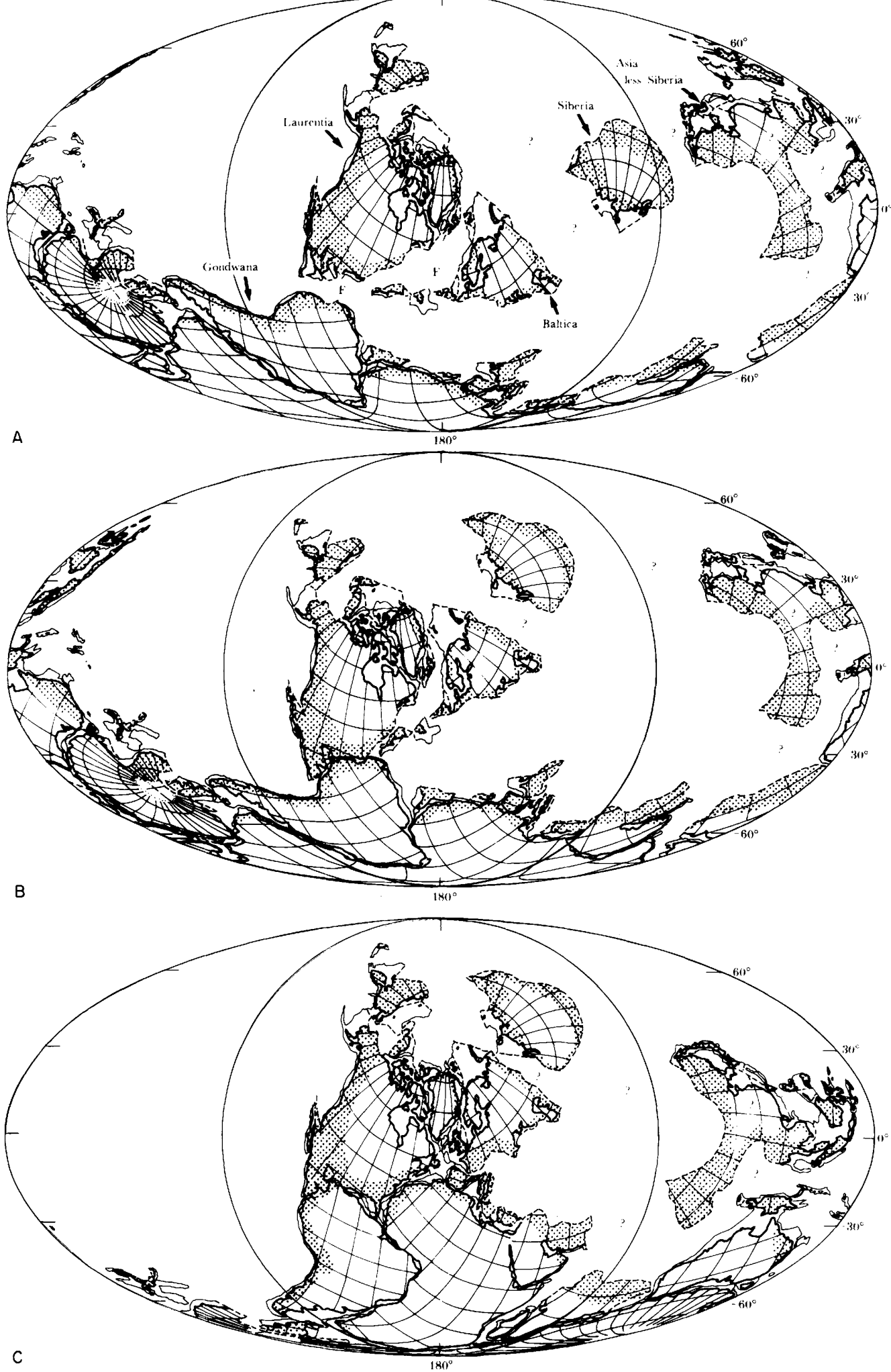

FIG. 7. Global reconstructions due to Livermore et al. (1985) (Mollweide elliptical projection) (stippled areas denote an approximate extent of orogenic deformation of the same age as the map or younger; $F$ indicates that longitude separation is based on fossil evidence; ? in oceanic regions indicates uncertain longitudinal separation; ? in continental regions indicates that no palaeomagnetic data are available): (A) Caradoc-Wenlock time; (B) Ludlow-Emsian time; (C) Eifelian-Tournaisian time. 

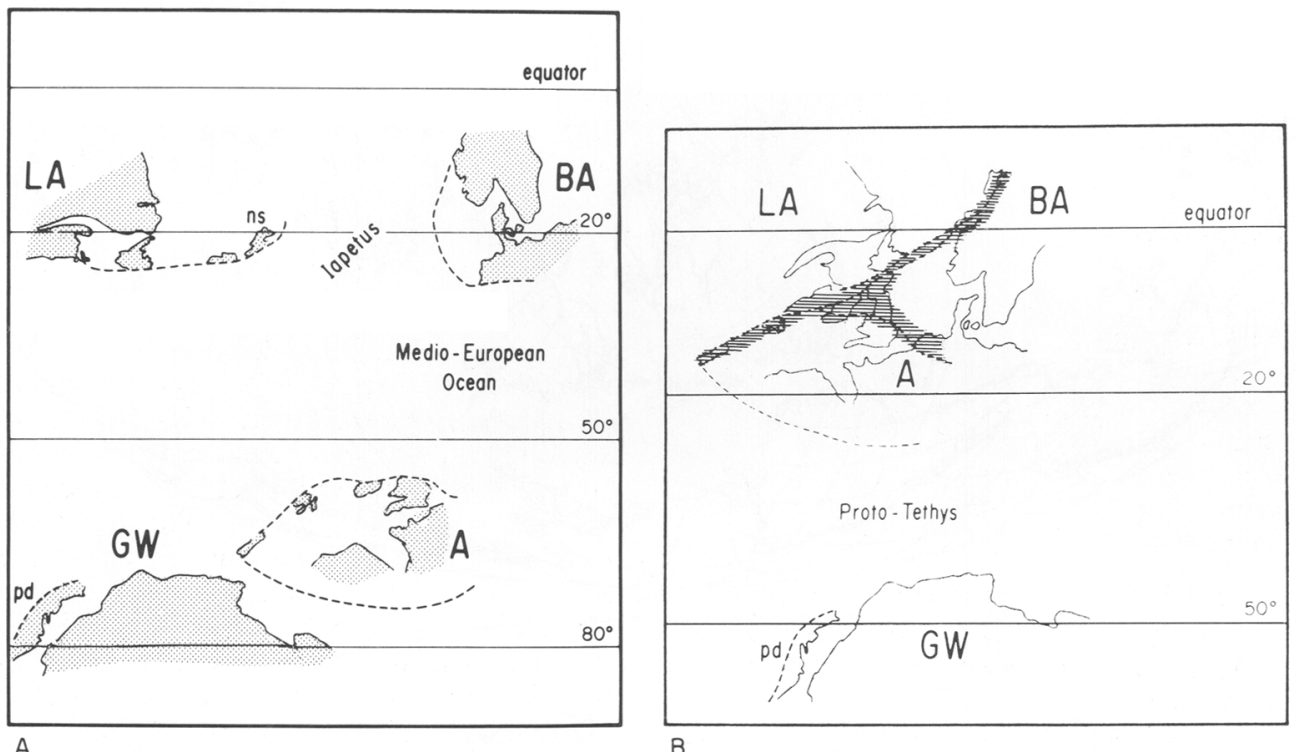

FIG. 8. Sketch maps of the palaeocontinental positions proposed by Perroud et al. (1984) (A, Armorica; GW, Gondwana; BA, Baltica; LA, Laurentia; ns, northern Scotland; pd, Delaware Piedmont); shaded zones in (B) are areas of collision between plates: (A) Ordovician; (B) Devonian.

subsequent configuration of Pangaea, and depicts most of the continents already in one reassembly with Siberia arbitrarily not far removed from Russia and with eastern Asia arbitrarily positioned. Laurentia-Baltica is positioned on this map using data from Britain, Avalonia, central Europe and Iberia. This places it in a very similar position to that indicated by the revised data from the Mauch Chunk Formation (Kent \& Opdyke 1985) and the data from the Canadian Maritimes (Roy \& Morris 1983). Watts (1985) has shown that data from Spitzbergen are consistent with the position in Fig. 7(C).

\section{Palaeomagnetic overprints}

In this paper we have emphasized primary magnetizations and the difficulty of distinguishing them when secondary overprinting has occurred. However, the overprints themselves are of considerable importance as indicators of the diagenesis or metamorphism which causes them, and when the secondary remanence can be dated they are as useful as any other data for palaeomagnetic purposes.

For example, among the British data (Fig. 3B) is a sequence from the Aberdeenshire gabbros (Watts \& Briden 1984) in which palaeomagnetic direction changes systematically with cooling age as determined independently by $\mathrm{K}-\mathrm{Ar}$ studies
(Dewey \& Pankhurst 1970). It seems that the NRM is either viscous PTRM acquired during cooling to about $500^{\circ} \mathrm{C}$, as the original investigators suggested, or CRM acquired during the last stages of cooling, i.e. significantly later but still related to the post-orogenic cooling and still indicative of its progression in time and space. Thus the data can be used, as here, to contribute to the local APW path, although the absolute age of remanence may not be unambiguously known. Conversely, if the magnetization process were clear the data could also be used to refine the post-orogenic cooling pattern for this terrane and to provide temperature-time points for elucidation of its history of uplift and unroofing.

Late Palaeozoic overprinting of older rocks has been a major phenomenon and is of interest in its own right. It is likely to be related to diagenetic redeposition of iron oxides owing to groundwater circulation in the widespread arid climates of the Permo-Carboniferous (French \& Van der Voo 1977, Scotese et al. 1982, McCabe et al. 1983, Irving \& Strong 1984a, Seguin \& Michaud 1985). In many rocks, particularly permeable sediments, overprinting amounts to total remagnetization. However, even massive igneous and metamorphic rocks from well outside the HercynianAlleghanian belt, where cooling effects would have been operative, have been affected (Roy et al. 1983, Briden \& Mullen 1984). The data are useful additions to the late Palaeozoic data base 
where precise ages can be attached to them, and the phenomenon is worthy of much magnetic and micro-mineralogical study of the processes that are involved.

\section{Discussion}

The maps in Figs 7 and 8 are extremely speculative because of the sparse data set and its uneven quality. The data amount to only a fraction of what is required for optimum palaeomagnetic control on evolution of the orogen. Nevertheless, limited but useful palaeomagnetic constraints upon the evolution of the belt can be deduced from the present data.

1 The Baltic and Laurentian shields may have been adjacent in the late Proterozoic before the opening phase of the Caledonian-Appalachian Wilson cycle.

2 In the Ordovician, Laurentia and Baltica were in similar palaeolatitudes and the convergence which caused the Scandinavian and British Caledonides must therefore have been principally along the lines of palaeolatitude.

3 The Armorican and Bohemian massifs comprised an 'Armorica' plate which was in high southerly latitudes in the early Palaeozoic but contiguous with Laurentia-Baltica by Devonian time; its convergence could coincide with and partially account for Acadian-Caledonian orogenic phases and perhaps for the 'third arm' of the Caledonides through central Europe.

4 Gondwanaland began to collide with the northern supercontinent in the late Devonian or early Carboniferous. Repercussions of this collision constituted Carboniferous orogeny in the southern Appalachians-Hercynides.

However, the data are neither sufficiently complete nor sufficiently refined to assist greatly in resolving such vital questions as (a) the nature of the central European Caledonides (Ordovician data from the Baltic shield and Russian platform, and Cambrian data from England are required for this purpose) and (b) the relative roles of dextral and sinistral displacements during orogenesis. To remedy this we require many more data, particularly from the cratonic and platform regions in which primary magnetizations are resolved from secondary overprints. This is a task requiring the highest standards of analysisstandards which have not always been attained even in some recent studies - and will need to be integrated with tectonic and mineralogical study. Such work may contribute to knowledge of the metamorphic and diagenetic history of the region as well as to its evolving reassembly.

ACKNOWLEDGMENT: We acknowledge usefuldiscussion and preprints of papers by $\mathrm{E}$. Irving.

\section{References}

Bachtadse, V., Heller, F. \& KröneR, A. 1983. Palaeomagnetic investigations in the Hercynian mountain belt of central Europe. Tectonophysics, 91, 285-99.

BAMbaCh, R. K., Scotese, C. R. \& Ziegler, A. M. 1980. Before Pangaea: the geographies of the Palaeozoic world. American Scientist, 68, 2638.

Briden, J. C. \& Duff, B. A. 1981. Pre-Carboniferous paleomagnetism of Europe north of the Alpine orogenic belt. In: McElhinNy, M. W. \& VALENCIO, D. A. (eds) Paleoreconstruction of the Continents, Geodynamics Series, Vol. 2, pp. 137-49, American Geophysical Union and Geological Society of America, Washington, DC.

- \& Mullen, A. J. 1984. Superimposed Recent, Permo-Carboniferous and Ordovician palaeomagnetic remanence in the Builth Volcanic Series, Wales. Earth and Planetary Science Letters, 69, 413-34.

- - TuRnell, H. B. \& Watts, D. R. 1984. British paleomagnetism, Iapetus Ocean and the Great Glen fault. Geology, 12, 428-31.

- - IRONS, J. \& JoHnson, P. A. 1971. Palaeomagnetic studies of the Caerfai Series and the Skomer
Volcanic Group (Lower Palaeozoic, Wales). Geophysical Journal of the Royal Astronomical Society, 22, 1-16.

_- Morris, W. A. \& Piper, J. D. A. 1973. Palaeomagnetic studies in the British Caledonides-VI. Regional and global implications. Geophysical Journal of the Royal Astronomical Society, 34, 10734.

BuChan, K. L., FAhrig, W. F., Freda, G. N. \& Frith, R. A. 1983. Paleomagnetism of the Lac St. Jean anorthosite and related rocks, Grenville province, Quebec. Canadian Journal of Earth Sciences, 20, 246-58.

Bullard, E. C., Everett, J. \& Smith, A. G. 1965. The fit of the continents around the Atlantic. Philosophical Transactions of the Royal Society of London, Series A, 258, 41-51.

Chamalaun, F. H. \& Creer, K. M. 1964. Thermal demagnetization studies on the Old Red Sandstone of the Anglo-Welsh cuvette. Journal of Geophysical Research, 69, 1607-16.

Claesson, K. C. \& Turner, P. 1980. Diagenetic magnetization of the Caerfai Bay Shales (Cambrian), South Wales. Geophysical Journal of the Royal Astronomical Society, 60, 95-106. 
Creer, K. M. 1968. Palaeozoic palaeomagnetism. Nature, London, 219, 246-50.

DANKers, P. 1982. Implications of Early Devonian poles from the Canadian Arctic Archipelago for the North American apparent polar wander path. Canadian Journal of Earth Sciences, 19, 1802-9.

DeUTSCH, E. R. 1980. Magnetism of the Mid-Ordovician Tramore volcanics, SE Ireland, and the question of a wide Proto-Atlantic ocean. Advances in Earth and Planetary Sciences, 10, 77-98.

DEWEY, J. F. \& PANKhuRST, R. J. 1970. The evolution of the Scottish Caledonides in relation to their isotopic age pattern. Transactions of the Royal Society of Edinburgh, 68, 361-89.

DufF, B. A. 1980. The palaeomagnetism of Jersey volcanics and dykes, and the Lower Palaeozoic apparent polar wander path for Europe. Geophysical Journal of the Royal Astronomical Society, 60, 355-75.

Everitt, C. W. F. \& Belshé, J. C. 1960 . Palaeomagnetism of the British Carboniferous system. Philosophical Magazine, 5, 675-85.

French, A. N. \& VAN DER Voo, R. 1979. The magnetization of the Rose Hill Formation at the classical site of Graham's fold test. Journal of Geophysical Research, 84, 7688-96.

French, R. B. \& VAN Der Voo, R. 1977. Remagnetization problems with the palaeomagnetism of the Middle Silurian Rose Hill Formation of the Central Appalachians. Journal of Geophysical Research, 82, 5803-6.

Hagstrum, J. T., Van der Voo, R., Auvray, B. \& BONHOMMET, N. 1980. Eocambrian-Cambrian palaeomagnetism of the Armorican Massif, France. Geophysical Journal of the Royal Astronomical Society, 61, 489-517.

van Hilten, D. 1964. Evaluation of some tectonic hypotheses by paleomagnetism. Tectonophysics, $\mathbf{1}$, $1-71$.

Irving, E. 1964. Paleomagnetism and its Application to Geological and Geophysical Problems, Wiley, New York.

_ \& Strong, D. F. 1984a. Paleomagnetism of the early Carboniferous Deer Lake Group western Newfoundland: no evidence for Carboniferous displacement of 'Acadia'. Earth and Planetary Science Letters, 69, 374-91.

\& — 1984b. Evidence against large-scale Carboniferous strike-slip faulting in the Appalachian-Caledonian orogen. Nature, London, $\mathbf{3 1 0}$, 762-4.

Kanasewich, E. R., Havskov, J. \& Evans, M. E. 1978. Plate tectonics in the Phanerozoic. Canadian Journal of Earth Sciences, 15, 919-55.

Kent, D. V. 1982. Palaeomagnetic evidence for postDevonian displacement of the Avalon platform (Newfoundland). Journal of Geophysical Research, 87, 4441-50.

—_ \& KePPIE, J. D. 1988. Silurian-Permian palaeocontinental reconstructions and circum-Atlantic tectonics. This volume.

\& OPDYKE, N. D. 1979. The early Carboniferous palaeomagnetic field of North America and its bearing on tectonics of the northern Appalachians. Earth and Planetary Science Letters, 44, 565-72.

\& — 1985. Multicomponent magnetizations from the Mississippian Mauch Chunk Formation of the central Appalachians and their tectonic implications. Journal of Geophysical Research, 90 , 5371-83.

—, Dia, O. \& Sougy, J. M. A. 1984. Paleomagnetism of Lower-Middle Devonian and upper Proterozoic-Cambrian (?) rocks from Mejeria (Mauritania, West Africa). In: VAN DER VOO, R., SCOTESE, C. R. \& BONHOMMET, N. (eds) Plate Reconstruction from Paleozoic Paleomagnetism, Geodynamics Series, Vol. 12, pp. 99-115, American Geophysical Union, Washington, DC

Khramov, A. N., Petrova, G. N.\& Pechersky, D. M. 1981. Paleomagnetism of the Soviet Union. In. McElhinny, M. W. \& Valencio, D. A. (eds) Paleoreconstruction of the Continents, Geodynamics Series, Vol. 2, pp. 177-94, American Geophysical Union and Geological Society of America, Washington, DC.

LAPOINTE, P. L. 1979. Paleomagnetism and orogenic history of the Botwood Group and Mount Peyton Batholith, Central Mobile Belt, Newfoundland. Canadian Journal of Earth Sciences, 16, 866-76.

Livermore, R. A., SMith, A. G. \& Briden, J. C. 1985. Palaeomagnetic constraints on the distribution of continents in the late Silurian and early Devonian. Philosophical Transactions of the Royal Society of London, Series B, 309, 29-56.

MCCABE, C. \& VAN DER Voo, R. 1983. Paleomagnetic results of the Late Keweenawan Chequamegon Sandstone and implications for red bed diagenesis and Late Precambrian apparent polar wander of North America. Canadian Journal of Earth Sciences, 20, 105-12.

, - , Peacor, D. R., Scotese, C. R. \& Freeman, R. 1983. Diagenetic magnetite carries ancient yet secondary remanence in some Paleozoic sedimentary carbonates. Geology, 11, 221-3.

,,- WilKinSON, B. H. \& DEVANEY, K. 1985. A middle/late Silurian palaeomagnetic pole from limestone reefs of the Wabash Formation (Indiana, USA). Journal of Geophysical Research, 90, 295965 .

MCClelland Brown, E. 1983. Palaeomagnetic studies of fold development in the Pembrokeshire Old Red Sandstone. Tectonophysics, 98, 131-49.

MCElhinny, M. W. 1973. Palaeomagnetism and Plate Tectonics, Cambridge University Press, Cambridge.

Morel, P. \& IRving, E. 1978. Tentative palaeocontinental maps for the early Phanerozoic and Proterozoic. Journal of Geology, 86, 536-61.

\& - 1981. Paleomagnetism and the evolution of Pangea. Journal of Geophysical Research, 86, 1858-72.

MoRRIs, W. A. 1976. Transcurrent motion determined palaeomagnetically in the Northern Appalachians and Caledonides and the Acadian Orogeny. $\mathrm{Ca}$ nadian Journal of Earth Sciences, 13, 1236-43.

Nevanlinna, H. \& Pesonen, L. J. 1983. Late Precambrian Keweenawan asymmetric polarities as ana- 


\section{Palaeomagnetic constraints on evolution of orogen}

lyzed by axial offset dipole geomagnetic models. Journal of Geophysical Research, 88, 645-58.

Perigo, R., Van der Voo, R., Auvray, B. \& BonHOMMET, N. 1983. Palaeomagnetism of late Precambrian-Cambrian volcanics and intrusives from the Armorican massif, France. Geophysical Journal of the Royal Astronomical Society, 75, 23560.

Perroud, H., VAN DeR VOo, R. \& Bonhommet, N. 1984. Palaeozoic evolution of the Armorica plate on the basis of palaeomagnetic data. Geology, 12, 579-82.

Piper, J. D. A. 1979. Aspects of Caledonian palaeomagnetism and their tectonic implications. Earth and Planetary Science Letters, 44, 176-92.

-_ 1981. Magnetic properties of the Alnön complex. Geologiska Föreningens $i$ Stockholm Förhandlingar, 103, 9-15.

RAO, K. V. \& VAN DER VOO, R. 1979. Paleomagnetism of a Paleozoic anorthosite from the Appalachian Piedmont, Northern Delaware: possible tectonic implications. Earth and Planetary Science Letters, 47, $113-20$

RoY, J. L. 1982. Paleomagnetism of Siluro-Devonian rocks from eastern Maine: discussion. Canadian Journal of Earth Sciences, 19, 225-32.

- 1983. Paleomagnetism of the North American Precambrian: a look at the data base. Precambrian Research, 19, 319-48.

- \& MoRRIS, W. A. 1983. A review of paleomagnetic results from the Carboniferous of North America; the concept of Carboniferous geomagnetic field horizon markers. Earth and Planetary Science Letters, 65, 167-81.

—, OpdyKe, N. D. \& IRving, E. 1967. Further paleomagnetic results from the Bloomsburg Formation. Journal of Geophysical Research, 72, 507586.

—- TANCZYK, E. \& Lapointe, P. 1983. The paleomagnetic record of the Appalachians. In: SCHENK, P. W. (ed.) Regional Trends in the Geology of the Appalachian-Caledonian-Hercynian-Mauritanide Orogen, pp. 11-26, Reidel, Dordrecht.

Scotese, C. R. 1984. Palaeozoic palaeomagnetism and the assembly of Pangaea. In: VAN DER Voo, R., SCOTESE, C. R. \& BONHOMMET, N. (eds) Plate Reconstruction from Paleozoic Paleomagnetism, Geodynamics Series, Vol. 12, pp. 1-10, American Geophysical Union, Washington, DC.

-, BAMBaCh, R. K., Barton, C., VAN DER Voo, R. \& ZIEGLER, A. M. 1979. Palaeozoic base maps. Journal of Geology, 87, 217-77.

- , VAN DER Voo, R. \& MCCABE, C. 1982. Paleomagnetism of the Upper Silurian and Lower Devonian carbonates of New York State: evidence for secondary magnetizations residing in magnetite. Physics of the Earth and Planetary Interiors, 30 , 385-95.

Seguin, M. K. \& GaHÉ 1985. Paleomagnetism of Lower Devonian volcanics and Devonian dykes from north central New Brunswick, Canada. Physics of the Earth and Planetary Interiors, 38, 262-76.

\& Michaud, C. 1985. The Bécancour-Yamaska,
Quebec: a palaeomagnetic study. Journal of Geomagnetism and Geoelectricity, 37, 895-912.

-_, SINGH, A. \& FYFFE, L. 1985. New paleomagnetic data from Carboniferous volcanics and red beds from Central New Brunswick. Geophysical Research Letters, 12, 81-4.

Smith, A. G. \& Hallam, A. 1970. The fit of the southern continents. Nature, London, 225, 139-44.

- Briden, J. C. \& Drewry, G. E. 1973. Phanerozoic world maps. Organisms and Continents through Time, Special Paper of the Palaeontological Association No. 12, pp. 1-42.

—, Hurley, A. M. \& Briden, J. C. 1981. Phanerozoic Palaeocontinental World Maps, Cambridge University Press, Cambridge, 102 pp.

Smith, R. L., Stearn, J. E. F. \& Piper J. D. A. 1983. Palaeomagnetic studies of the Torridonian sediments, NW Scotland. Scottish Journal of Geology, $19,29-45$.

Spariosu, D. J. \& Kent, D. V. 1983. Palaeomagnetism of the Lower Devonian Traveler Felsite and the Acadian orogeny in the New England Appalachians. Bulletin of the Geological Society of America, 94, 1319-28.

Stearn, J. E. F. \& PiPer, J. D. A. 1984. Palaeomagnetism of the Sveconorwegian mobile belt of the Fennoscandian shield. Precambrian Research, 23 201-46.

Tarling, D. H., Donovan, R. N., Abou-Deeb, S. M. \& El-Batrouk, S. I. 1976. Palaeomagnetic dating of hematite genesis in Orcadian basin sediments. Scottish Journal of Geology, 12, 125-34.

Thomas, C. \& BRIDEN, J. C. 1976. Anomalous geomagnetic field during the late Ordovician. Nature, London, 259, 380-2.

Torsvik, T. H. 1984. Palaeomagnetism of the Foyers and Strontian Granites, Scotland. Physics of the Earth and Planetary Interiors, 36, 163-77.

- LøVLIE, R. \& STORETVEDT, K. M. 1983. Multicomponent magnetization in the Helmsdale granite, North Scotland; geotectonic implication. Tectonophysics, 98, 111-29.

TURNER, S. \& TARLING, D. H. 1982. Thelodont and other agnathan distributions as tests of Lower Palaeozoic continental reconstructions. Palaeogeography, Palaeoclimatology, Palaeoecology, 39, 295-311.

VAN DER VOO, R. 1979. Palaeozoic assembly of Pangaea: a new plate tectonic model for the Taconic, Caledonian and Hercynian orogenies. EOS, Transactions of the American Geophysical Union, 60, 241 (abstract).

1981. Paleomagnetism of North America: a brief review. In: McElhinny, M. W. \& Valencio, D. A. (eds) Paleoreconstruction of the Continents, Geodynamics Series, Vol. 2, pp. 159-76, American Geophysical Union and Geological Society of America, Washington, DC.

\& FRENCH, R. B. 1974. Apparent polar wandering for the Atlantic-bordering continents: Late Carboniferous to Eocene. Earth-Science Reviews, 10, 99-119.

\& Scotese, C. R. 1981. Paleomagnetic evidence for a large $(2,000 \mathrm{~km})$ sinistral offset along the 
Great Glen fault during Carboniferous time. Geology, 9, 583-9.

--, French, A. N. \& French, R. B. 1979. A paleomagnetic pole position from the folded Upper Devonian Catskill redbeds, and its tectonic implications. Geology, 7, 345-8.

, French, R. B. \& Williams, D. W. 1976. Paleomagnetism of the Wilberns Formation (Texas) and the Late Cambrian paleomagnetic field for North America. Journal of Geophysical Research, 81, 5633-8.

—, Jones, M., Gromme, C. S., Eberlein, G. C. \& ChURKIN, M. JR 1980. Paleozoic paleomagnetism and northward drift of the Alexander Terrane, Southeastern Alaska. Journal of Geophysical Research, 85, 5281-96.

, Peinado, J. \& Scotese, C. R. 1984. A paleomagnetic reevaluation of Pangaea reconstructions. In: VAN DER VOO, R., SCOTESE, C. R. \& BONHOMMET, N. (eds) Plate Reconstruction from Paleozoic Paleomagnetism, Geodynamics Series, Vol. 12, pp. 11-16, American Geophysical Union, Washington, DC.
Watts, D. R. 1985. Palaeomagnetism of the Lower Carboniferous Billefjorden Group, Spitsbergen. Geological Magazine, 122, 383-8.

- \& BRIDEN, J. C. 1984. Palaeomagnetic signature of slow post-orogenic cooling of the northeast Highlands of Scotland recorded in the Newer Gabbros of Aberdeenshire. Geophysical Journal of the Royal Astronomical Society, 77, 775-88.

ZIEGLER, P. A. 1984. Caledonian and Hercynian crustal consolidation of western and central Europe-a working hypothesis. Geologie en Mijnbouw, 63, 93108.

ZONENSHAyn, L. P. \& GoRodnitskiY, A. M. 1977a. Paleozoic and Mesozoic reconstructions of the continents and oceans. Article 1. Early and Middle Paleozoic reconstructions. Geotectonics, 11, 8394.

\& __ 1977b. Paleozoic and Mesozoic reconstructions of the continents and oceans. Article 2. Late Paleozoic and Mesozoic reconstructions. Geotectonics, 11, 159-72.

J. C. BRIDEN, Department of Earth Sciences, University of Leeds, Leeds LS2 9JT, UK. Now at Natural Environment Research Council, Swindon SN2 IEU, UK

D. V. KENT, Lamont-Doherty Geological Observatory, Palisades, New York, NY 10964, USA.

P. L. Lapointe \& J. L. RoY, Earth Physics Branch, Energy Mines and Resources, 1 Observatory Crescent, Ottawa K1A OY3, Canada.

R. A. Livermore \& A. G. Smith, Department of Earth Sciences, University of Cambridge, Downing Street, Cambridge CB2 3EQ, UK. R.A.L. now at British Geological Survey, Keyworth, Nottingham NG12 5GG, UK.

M. K. SEguIN, Department of Geology, Université Laval, Quebec City, Quebec G1K 7P4, Canada.

R. VAN DER Voo, Department of Geological Sciences, University of Michigan, Ann Arbor, MI 48109, USA.

D. R. WATTS, Department of Geology, University of Glasgow, Glasgow G12 8QQ, UK. 